\title{
The Electronic Library
}

E-books in Spanish academic libraries

Luisa Alvite Díez and Blanca Rodríguez Bravo

\section{Article information:}

To cite this document:

Luisa Alvite Díez and Blanca Rodríguez Bravo, (2009),"E\#books in Spanish academic libraries", The

Electronic Library, Vol. 27 Iss 1 pp. 86 - 95

Permanent link to this document:

http://dx.doi.org/10.1108/02640470910934614

Downloaded on: 02 September 2014, At: 03:48 (PT)

References: this document contains references to 23 other documents.

To copy this document: permissions@emeraldinsight.com

The fulltext of this document has been downloaded 1005 times since 2009*

\section{Users who downloaded this article also downloaded:}

Rebecca C. Walden, (2006),"e-Books from EBSCO: A Natural Fit", Library Hi Tech News, Vol. 23 Iss 5 pp. Linda Ashcroft, (2011),"Ebooks in libraries: an overview of the current situation", Library Management, Vol. 32 Iss 6/7 pp. 398-407

(2002),"ebrary: building bridges between islands of information: an email interview with Christopher

Warnock, CEO, ebrary (http://www.ebrary.com)", VINE, Vol. 32 Iss 2 pp. 52-54

Access to this document was granted through an Emerald subscription provided by 408686 []

\section{For Authors}

If you would like to write for this, or any other Emerald publication, then please use our Emerald for Authors service information about how to choose which publication to write for and submission guidelines are available for all. Please visit www.emeraldinsight.com/authors for more information.

\section{About Emerald www.emeraldinsight.com}

Emerald is a global publisher linking research and practice to the benefit of society. The company manages a portfolio of more than 290 journals and over 2,350 books and book series volumes, as well as providing an extensive range of online products and additional customer resources and services.

Emerald is both COUNTER 4 and TRANSFER compliant. The organization is a partner of the Committee on Publication Ethics (COPE) and also works with Portico and the LOCKSS initiative for digital archive preservation.

\footnotetext{
*Related content and download information correct at time of download.
} 
EL

27,1

\section{6}

Received 10 December 2007

Revised 2 February 2008

Accepted 12 February 2008

\title{
E-books in Spanish academic libraries
}

\author{
Luisa Alvite Díez and Blanca Rodriguez Bravo \\ Faculty of Philosophy and Letters, University of León, León, Spain
}

\author{
Abstract \\ Purpose - This study aims to explore the current presence of e-books in the collections of Spanish \\ academic libraries, from the viewpoint of the contents on offer.
}

Design/methodology/approach - Exploration of the library web sites was undertaken in order to gauge the level of presence of packages that distribute electronic books. In evaluating the extent of content available, the data recorded were compared with those derived from another research carried out in 2004. Similarly, an approximate indication of the topic areas with greatest representation was attempted, distinguishing multi-disciplinary suppliers from those specializing in one field.

Findings - Out of the 50 existing universities 36 support the subscription of at least one collection of electronic books. The universities of the communities of Andalusia, Catalonia and Valencia are those that have reached a greater implementation of e-books. There is a considerable diversity - many universities have subscribed to collections specializing in literature and in the field of engineering. The main multi-disciplinary collections purchased by libraries are E-libro and NetLibrary.

Practical implications - This is a sector that is definitely taking off in Spain and will require progressive acceptance on the part of the academic community. Librarians have the responsibility to aid their users in understanding the growing complexity of the information market and the increasing range of resources available for research.

Originality/value - The research is a necessary approach to the integration of collections of e-books into Spanish public universities. Encouraging the use of monographs in electronic format takes on great importance, when it is borne in mind that e-books will have a crucial role in the new model for education advocated by the European Higher Education Area (EHEA).

Keywords Academic libraries, Electronic books, Collections management, Spain

Paper type General review

\section{Introduction}

The term "electronic book" is currently used with two meanings. On the one hand, it is in use to refer to contents available in digital format and not directly readable by humans without the aid of a computer. On the other hand, it is employed as a name for a range of pieces of portable equipment, similar to computers, specifically designed to permit reading of contents in digital form, and copying the shape and size of a conventional book. For this reason, Rao (2005) points out that the expression "e-book" is used simultaneously to describe contents, format, reading software and reader apparatus.

As was highlighted by Landoni and Gibb (2000) an electronic book is the result of integrating classical book structure, or rather the familiar concept of a book, with features that can be provided within an electronic environment, which is interpreted as an interactive document that can be composed and read on a computer. However, Bennett and Landoni (2005) point out that if e-books are to reach their full potential, they will have to offer more than simply an electronic version of the printed books. Adopting a user-centred approach four dimensions are to be considered: content, format, purpose and use.
The Electronic Library Vol. 27 No. 1, 2009 pp. $86-95$

Emerald Group Publishing Limited 0264-0473

DOI $10.1108 / 02640470910934614$ 
The success expected for electronic books with dedicated reader equipment has not materialized yet. In a user evaluation (International Digital Publishing Forum, 2006) the most desirable attributes of a successful e-book reader emerged to be: low costs for the devices, compatibility with multiple file-formats, low weight, long battery life and high screen resolution. According to Just (2007) the supply of e-books titles has grown by an average of 20 per cent annually over the last 20 years and Landoni and Hanlon (2007) consider that electronic books are becoming an increasingly viable format due to the emergence of PDAs.

A different route has been followed by developments in electronic books and reference works designed for the web. In fact, as Rao (2005) points out, e-books form the "third wave" in the field of electronic publishing, after reference databases and electronic journals, already fully consolidated. This model of electronic book has benefited from the standardization inherent in technological formats like HTML, XML or PDF. Publishers and aggregators have included among their products electronic books, principally of a scientific type, attractive to the academic sector.

According to the study carried out by the company Gold Leaf commissioned by Joint Information Systems Committee (JISC) (Bennett, 2003), electronic books may aid in solving some of the challenges currently faced by higher education. Among these he lists changes in student profiles involving age, employment, the growing number of distance-learning students, the adoption of learning-management systems, environments for virtual education, and the like. However, as the report itself says, the distribution chain for e-books is imperfect. The sparse knowledge shown by the principal groups of users, university teachers and students, and in some cases of specific products, even by librarians, constitutes the chief barrier to the success of electronic books. To this main obstacle are added others, such as the unwillingness of many publishers to issue books in digital format or the policies on prices and subscriptions established by publishing and aggregating firms.

In the recent survey conducted in 2007 by ebrary, a leading provider of e-content services and technology, it was discovered that users - mainly from academic libraries in the USA - continue to prefer printed books to electronic by a 4 per cent margin. McKiel (2007) analyses the data collected and claims that this situation arises from two main factors: unfamiliarity with the possibilities for research offered by electronic books and the difficulties presented by interfaces. Users are not aware of the fact that electronic books are not intended to be read from start to finish and so do not value the functions they implement for seeking out contents. This scholar holds the opinion that users consider printed books superior by reason of their portability and ease of reading.

In Spain, e-books, which until recently had only a limited development in terms of reference works, appear to be heading for a promising future in academic libraries, when consideration is given to the changes in university teaching that will be introduced by the effects of the European Higher Education Area, which prioritizes giving students skills that allow them to learn how to learn. This transformation implies backing for teaching not requiring constant attendance and for e-learning, in which the university library will become a Learning Resource Centre, a library which will expand and converge with other services: computing, multimedia production services and so forth.

This paper takes as a starting point previous work done by its authors. One piece is the analysis carried out with the grant provided by the Spanish Ministry of Education 
$\mathrm{EL}$

27.1

within its 2004 Programme for Study and Analysis (Rodríguez Bravo, 2004)[1], in which it was shown that the implementation of collections of e-books was rare in Spanish universities, as well as being limited to certain specific topic areas. Another is the recent investigation of the state of change in the introduction of collections of electronic books in Spanish academic libraries (Alvite Díez and Rodríguez Bravo, 2006).

Likewise, account is also taken of the outcomes of the survey performed world-wide by ebrary in March 2007, the summary of the results of which this firm made available to the librarianship community in June of that year (McKiel, 2007).

\section{Objectives and methodology}

This study explores the current presence of e-books in the collections of Spanish academic libraries, from the viewpoint of the contents on offer. This was done by trawling the web sites of all of the state universities in Spain so as to discover for what packages of electronic works they had contracts. This was on the basis of the list of public Spanish universities provided by the Spanish Ministry of Education and Science (www.mec.es/univ/).

The last exploration of the library web sites was undertaken during August 2007. It was noted that there was a great diversity in the criteria relating to the way the collections of books for which there are contracts are promoted, which caused difficulties in achieving a precise count of resources.

In order to gauge the level of presence, in the light of the heterogeneity that was found, the set of material to be studied was delimited by restricting it to those packages that distribute electronic books. The reference works in digital format were disregarded, as were collections of free books.

In evaluating the extent of content available, the data recorded were compared with those derived from the research carried out in 2004. Similarly, an approximate indication of the topic areas with greatest representation was attempted, distinguishing multi-disciplinary suppliers from those specializing in one field.

Data obtained from the survey carried out by ebrary (McKiel, 2007) were also taken into consideration. Among the 2,600 institutions invited to respond, the survey was completed by 552 libraries. Of these, 56 per cent were North American institutions, 17 per cent were European libraries and 16 per cent libraries in Asia. Of all the libraries that responded, 77 per cent were academic libraries.

\section{Results}

From trawling of the web pages of the libraries of Spanish public universities it can be stated that of the 50 universities currently in existence 36 have a subscription to at least one collection of electronic books (Table I). Universities in the Andalusian, Catalan and Valencian regions are those with the highest level of penetration of this type of product. Doubtless, the efforts put into joint acquisition by the Catalan Consortium of University Libraries (CBUC) and the Consortium of University Libraries of Andalusia (CBUA) have been crucial to this development.

As stated above, in completing the count the numerous reference works to which a good number of institutions have subscriptions, such as Harrison's Online, were not taken into consideration. This was also the case for certain specialized consultation materials in Medicine and Law. 


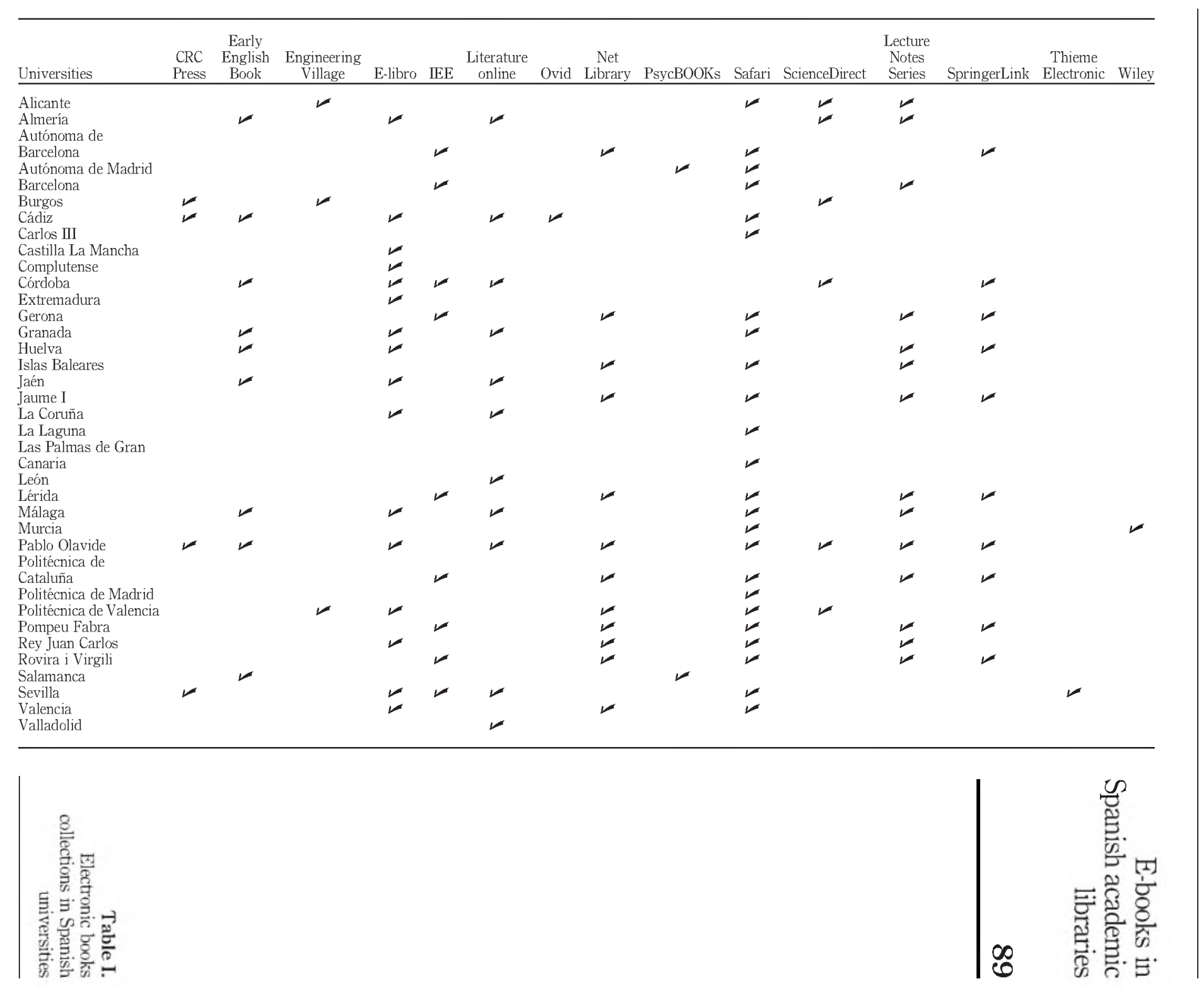


$\mathrm{EL}$

27.1

90

From the 14 Universities that do not hold subscriptions to e-books collections it can be pointed out the efforts of UNED (www.liberuned.com) promoting the publication of its own electronic books. As the survey carried out by ebrary (McKiel, 2007) noted, 56 per cent of the institutions that responded to the questions are already digitizing their materials or are in a preparatory phase for undertaking that task. The offering of contents they have produced themselves is a job that has been taken on board with increasing vigour by libraries over the last few years.

The products for which there were contracts presented considerable diversity. Many universities have subscribed to collections specializing in literature: Literature Online (LION), Early English Books Online (EEBO), Latin Patrology, and similar. Likewise, a good part of the collections of e-books under contract are in the field of engineering. This is the case for the packages Safari, Engineering Village2, or Lecture Notes in Computer Science (LNCS) and for the books, conference proceedings and standards of the provider of electronic content IEEE.

The main multi-disciplinary collections purchased by libraries are E-libro and NetLibrary. Together with these, account should be taken of the monographic contents distributed by the principal suppliers of electronic journals, such as ScienceDirect, SpringerLink and Wiley InterScience. The coverage of topics by these distributors was analysed by the authors in previous work (Rodríguez Bravo and Alvite Díez, 2005).

E-libro contains books mostly in English grouped into twelve collections, with representation of Arts, Social Sciences, Pure Sciences, Health and Natural Sciences and Technology. These have recently been complemented by the addition of the Cyberlibris collection, with 6,000 books on Economics and Business, and Greenwood which includes reference, academic and general interest e-books. It also contains collections of universal classics and classic works of Philosophy. Furthermore, it has, although in smaller numbers, specific works in Spanish and Portuguese.

NetLibrary groups its contents into packages aimed at academic and public libraries, companies and schools. The section prepared for academic libraries is subdivided into four large categories:

(1) Business;

(2) History;

(3) Sciences; and

(4) Education.

It also has a section called "e-Book Essentials" in which OCLC offers its recommended titles, organized into six collections:

(1) Academic;

(2) Business and Economics;

(3) Humanities;

(4) Science and Engineering;

(5) Social and Behavioural Sciences; and

(6) Public.

With regard to the number of e-books on offer in January 2008, the package with the greatest number of titles is NetLibrary, which has about 160,000 books. The overall 
coverage of E-Libro is in excess of 20,000 titles available for libraries, while close to 4,000 books are offered by Safari. Nonetheless, it should be pointed out that institutions are not obliged to purchase fixed packages. They can subscribe to just a part of the contents that the distributors can provide, so not all universities take identical lists of titles. Generally, the total number of books subscribed for by Spanish university libraries from NetLibrary is around 1,000 .

Almost all Spanish academic libraries have taken out subscriptions over the last few years to the products issued by Elsevier (ScienceDirect), Springer (SpringerLink) and John Wiley and Sons (Wiley InterScience). These concentrate on the distribution of serial publications, with books playing a secondary role. Nevertheless, their totals are significant: about 5,000 from Wiley (1,500 titles from Blackwell and 400 fromWiley-VCH), more than 24,000 from SpringerLink and 3,400 from ScienceDirect. However, only some libraries have a contract for these included in the licences for which they subscribe, with the remainder providing access only to abstracts and reference information.

It was clear that the number of e-books on offer has increased greatly in the last few years. In 2004 NetLibrary was offering 74,000 volumes, E-libro just over 1,000, Safari did not even reach the full thousand, Wiley had around half that number, Springer a little more than 2,500, with the titles in the Kluwer collection, now incorporated in SpringerLink, amounting to a further 1,200.

Figure 1 shows the principal collections for which Spanish universities have contracts, according to the count made on the basis of the information provided by the libraries themselves on their web sites.

The Proquest package of electronic books from Safari is the one most preferred by Spanish universities, having been subscribed to by almost half (24) of the institutions investigated. Ebrary's E-libro platform has been purchased by 16 universities and the OCLC collection from NetLibrary by 12 institutions.

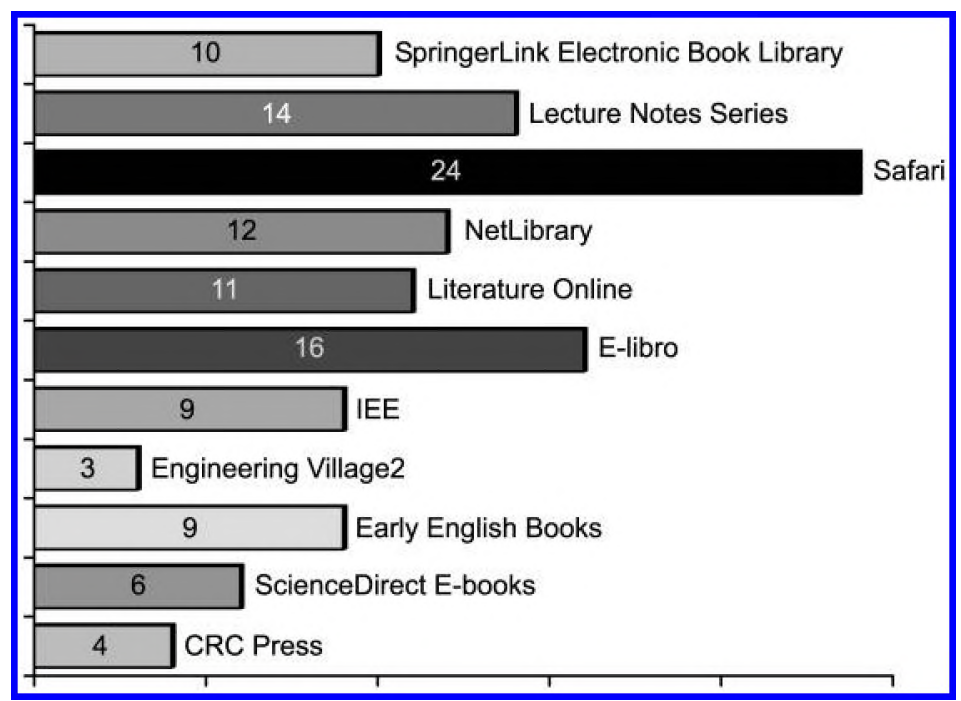

Figure 1. Distribution of electronic book collections in Spanish university libraries 
EL

27.1

92

A clear growth is noticeable in the purchasing of specific collections of e-books. In 2004 only the Catalan universities, which give access Netlibrary and Safari, and the Complutense University of Madrid, which had E-libro, hold contract these available.

It is also worth emphasizing the contracts taken out by 14 universities for the series Lecture Notes from Springer, in the majority of cases LNCS (Lecture Notes in Computer Science). The considerable offering of electronic books in the SpringerLink package has been subscribed to by ten institutions. It is also significant that nine universities provide access to the books, standards and conference proceedings of the IEEE package of technological contents, with subscriptions recently taken out by an appreciable number of Spanish universities.

It is striking that there is a noteworthy presence of electronic collections of literary works, those most widely in place being Literature Online (LION) and Early English Books. Ten universities have the first of these and nine the second, respectively. Other subscriptions are not so widespread. The collection of books from ScienceDirect is the principal package of scientific and technical contents on the market at the moment, but only six universities give access to its e-books, while the packages from CRC Press and Engineering Village2 are subscribed to by four and by three institutions respectively.

In the regions of Spain where the libraries are grouped into consortia, it can be seen how electronic book purchases have been completed jointly. Hence, the books on offer tend to be similar: all the Andalusian universities have the packages from E-libro, Early English Books Online, Literature Online (LION) and the Lecture Notes series from Springer. The Catalan universities, with their CBUC consortium, for their part offer the contents provided by NetLibrary, Safari and two of the products from Springer. Universities in Galicia (the BUGALICIA group) have a subscription to the books, proceedings and standards from IEEE. In Madrid the MADROÑO consortium does not show such a shared stance, with the Rey Juan Carlos University being the only one to have a subscription to the four most popular products. A similar state of affairs can be observed in Castile and Leon among the BUCLE consortium.

\section{Conclusions}

The integration of collections of e-books into Spanish public universities may be described as uneven. It does not appear that electronic books have yet carved out a sufficiently representative space for themselves among publications as a whole, even if their growth is undeniable. The modest level of implantation of e-books is noticeable if the data collected here are compared with the results from the survey by ebrary (McKiel, 2007), which established that 88 per cent of the libraries responding had subscriptions to collections of e-books and that 45 per cent provided access to more than 10,000 titles.

Nonetheless, this is a sector that is definitely taking off and will require progressive acceptance on the part of the academic community, having reached this point at a time when electronic journals already constitute an essential and unchallenged pillar of the collections in Spanish libraries.

There are difficulties in discovering precisely which products are purchased. Some universities publicize their subscriptions on their library web sites, including a section for electronic books, while others have the collections for which they have contracts scattered around among other electronic resources. In other cases, no explicit mention is made of them, yet it is possible to gain access to collections of e-books through the 
catalogue. As was highlighted by the report by McKiel (2007) based on the survey run by ebrary, the OPAC is the principal route for access to electronic books and thus what will promote them best. It would seem that an essential step in the integration of collections of electronic books will come from the incorporation of the corresponding bibliographic entries in Online Public Access Catalogues. Several universities are proceeding along these lines, with their catalogues having the possibility of delimiting searches to e-books specifically. Nevertheless the results of a 2006 survey of UK Higher E-books in
Spanish academic
libraries Education OPACs point out that despite the recommendations, only a minority of the OPACs examined allow users to restrict their searches to electronic resources generally, or e-books in particular (Belanger, 2007).

The Safari package of electronic books heads the list of preferences of Spanish universities, figuring among the subscriptions of almost half of the libraries studied. Next in the ratings come the E-libro platform and the OCLC collection (NetLibrary). The Lecture Notes Series from Springer and the e-books list proper from SpringerLink occupy a noteworthy position.

In Andalusian, Catalan and Valencian universities a striking presence of collections of e-books may be observed, which contrasts with the situation in other autonomous regions in the North of Spain. As for the topic areas of the packages subscribed to, a preference for technological fields may be observed as also for collections of classic literary texts. Relating to the great significance of Humanities collections, the study carried out by Levine-Clark (2007) at the University of Denver (USA), shows that humanists tend to be more aware of electronic books than their peers in other disciplines and they also tend to discover e-books through the catalogue.

The added value of E-libro and Netlibrary is related to their size and to the amount of content they have on offer. The functionality of these two platforms, like that of Safari, dedicated exclusively to the distribution of electronic books, is greater than what is to be found in the collections of suppliers who distribute electronic books as a sideline, as is the case for IEEE, ScienceDirect, SpringerLink or Wiley InterScience, who do no more than present a replica of the printed book.

As Landoni et al. (2000) highlight only limited work has been done in promote the definition of guidelines for the production of more effective electronic books or the definition of a set of rules in order to achieve an abstract object worthy of the label "electronic book". It would seem appropriate for firms supplying e-books to address the need to develop functions for accessing contents and for adapting to users that will permit electronic academic book to compete with printed versions. Nonetheless, it is necessary to point out that if users wish to read the complete book, the solution would lie in the availability of a reader apparatus equalling a printed book in portability and legibility. We agree with Just (2007) who claims that the development of title production in the end user market is important to librarians for two reason: First, most of the titles will not be published electronically if they cannot be sold on the regular market. Second, the title supply is an indicator for the acceptance of e-books by the end user.

For their part libraries will have to take a hand in training users. Teachers and students need a certain level of technological training in order to use the interfaces of the various suppliers in the optimum way. Training courses for users in this area are therefore crucial. The ebrary survey (McKiel, 2007) highlighted the fact that collections of electronic books and the tools they offer for research are not well understood by a 
EL

27,1

94

considerable percentage of students and researchers. Librarians have the responsibility to aid their users in understanding the growing complexity of the information market and the increasing range of resources available for research. In this sense Dinkelman and Stacy-Bates (2007) point out that librarians should remember to include e-books in library instruction sessions, as this provides another avenue to introduce and publicize e-books to patrons.

Encouraging the use of monographs in electronic format through training takes on yet greater importance, if that were possible, when it is kept in mind that e-books will have a crucial role in the new model for education advocated by the European Higher Education Area (EHEA). They will be essential for teachers' research activities and for the learning efforts of undergraduate and postgraduate students, as also for the distance education models which are increasingly in use.

\section{Note}

1. This was financed by the Secretariat of State for Education and Universities of the Spanish Ministry of Education, Culture and Sport within the Programme for Study and Analysis intended to improve the quality of higher education and the activities of university teachers.

\section{References}

Alvite Díez, M.L. and Rodríguez Bravo, B. (2006), "Colecciones de libros electrónicos en las bibliotecas universitarias españolas", 8as. Jornadas de Gestión de la Información: nuevas interfaces centradas en el usuario, tendencias en la organización de contenidos, documentos y bibliotecas, SEDIC, Madrid, pp. 147-59.

Belanger, J. (2007), "Cataloguing e-books in UK higher education libraries: report of a survey", Erogram: electronic librarv and information sustems, Vol. 41 No. 3, pp. 203-16.

Bennett, L. (2003), "Promoting the uptake of e-books in higher and further education", report prepared for JISC by Gold Leaf, London, available at: www.jisc.ac.uk/uploaded_ documents/PromotingeBooksReportB.pdf

Bennett, L. and Landoni, M. (2005), "E-books in academic libraries", The Electronic Library, Vol. 23 No. 1, pp. $9-16$.

Dinkelman, A. and Stacy-Bates, K. (2007), "Accessing e-books through academic library web sites”, College \& Research Libraries, January, pp. 45-58.

International Digital Publishing Forum (2006), "Ebook user survey 2006", available at: www. idpf.org/doc_library/surveys/IDPF_eBook_User_Survey_2006.pdf

Just, P. (2007), "Electronic books in the USA - their numbers and development and a comparison with Germany", Library Hi Tech, Vol. 25 No. 1, pp. 157-64.

Landoni, M. and Gibb, F. (2000), "The role of visual rhetoric in the design and production of electronic books: the visual book", The Electronic Library, Vol. 18 No. 3, pp. 190-201.

Landoni, M. and Hanlon, G. (2007), "E-book reading groups: interacting with e-books in public libraries", The Electronic Librany, Vol. 25 No. 5, pp. 599-612.

Landoni, M., Wilson, R. and Gibb, F. (2000), "From the visual book to the web book: the importance of design", The Electronic Librarv, Vol. 18 No. 6, pp. 407-19.

Levine-Clark, M. (2007), "Electronic books and the humanities: a survey at the University of Denver", Collection Building, Vol. 26 No. 1, pp. 7-14.

McKiel, A. (2007), Ebrary's Global eBook Survey. Sumey Analysis, available at: www.ebrary.com/ corp/collateral/en/Survey/ebrary_eBook_survey_2007.pdf 
Rao, S.S. (2005), "Electronic books: their integration into library and information centers", The Electronic Library, Vol. 23 No. 1, pp. 116-40.

Rodríguez Bravo, B. (2004), "Evaluación del acceso y gestión de los libros electrónicos en las bibliotecas universitarias españolas", research project, directed by Dr Blanca Rodríguez Bravo, available at: wwwn.mec.es/univ/html/informes/estudios_analisis/resultados_2004/ ea0115/ea0115.pdf

Rodríguez Bravo, B. and Alvite Díez, M.L. (2005), "Survey of the providers of electronic publications holding contracts with spanish university libraries", D-Lib Magazine, Vol. 11 No. 4, available at: www.dlib.org/dlib/april05/alvite/04alvite.html

\title{
Further reading
}

Barker, P. (2005), "Using e-books for knowledge management", The Electronic Library, Vol. 23 No. 1, pp. 5-8.

Eíto Brun, R. (2002), "El camino hacia el libro electrónico", El Profesional de la Información. Vol. 11 No. 1, pp. 52-63.

Herther, N.H. (2005), "The e-book industry today: a bumpy road becomes an evolutionary path to market maturity", The Electronic Library, Vol. 23 No. 1, pp. 45-53.

Landoni, M. (2007), "E-book reading groups: interacting with e-books in public libraries", The Electronic Library, Vol. 25 No. 5, pp. 599-612.

Morris, A. and Balatsoukas, P. (2006), "Usability evaluation of Ebrary and Overdrive e-book online systems", Libraries without Walls, Facet Publishing, London, pp. 211-23.

Project EBONI: Electronic Books On-screen Interface (n.d.), project led by Monica Landoni. Strathclyde University, available at: http://ebooks.strath.ac.uk/eboni/documents/plan.html

Safley, ED. (2006), "Tearing down the walls: demand for e-books in an academic library", Libraries without Walls, Facet Publishing, London, pp. 224-32.

Snowihill, L. (2001), "E-books and their future in academic libraries: an overview", D-Lib Magazine, Vol. 7 Nos 7/8, available at: www.dlib.org/dlib/july01/snowhill/07snowhill.html

\begin{abstract}
About the authors
Luisa Alvite Díez is a Lecturer in the Department of Library and Information Science at the University of Leon, Spain. She focused her research interest on Information Retrieval, Interfaces, Electronic Libraries and Electronic resources. She is the corresponding author and can be contacted at: luisa.alvite@unileon.es

Blanca Rodriguez Bravo is Assistant Professor in the Department of Library and Information Science at the University of Leon, Spain. Her current research interest focus on Knowledge Organization, Interfaces, Electronic Libraries and Electronic resources.
\end{abstract}

To purchase reprints of this article please e-mail: reprints@emeraldinsight.com Or visit our web site for further details: www.emeraldinsight.com/reprints 


\section{This article has been cited by:}

1. Leila June Rod-Welch, Barbara E. Weeg, Jerry V. Caswell, Thomas L. Kessler. 2013. Relative Preferences for Paper and for Electronic Books: Implications for Reference Services, Library Instruction, and Collection Management. Internet Reference Services Quarterly 18:3-4, 281-303. [CrossRef]

2. Silas Marques de Oliveira. 2012. E-textbooks usage by students at Andrews University. Library Management 33:8/9, 536-560. [Abstract] [Full Text] [PDF]

3. Barbara Blummer, Jeffrey Kenton. 2012. Best Practices for Integrating E-books in Academic Libraries: A Literature Review From 2005 to Present. Collection Management 37:2, 65-97. [CrossRef]

4. Nuria Lloret Romero. 2011. The management of e-book collections and their implication on the economic management of the library. The Bottom Line 24:3, 173-179. [Abstract] [Full Text] [PDF]

5. José Antonio Cordón García, Julio Alonso Arévalo, Helena Martín Rodero. 2010. The emergence of electronic books publishing in Spain. Library Hi Tech 28:3, 454-469. [Abstract] [Full Text] [PDF]

6. Mercedes Baquero-Arribas. 2010. Libros electrónicos en la $<\mathrm{i}>$ Red de Bibliotecas del CSIC $<$ i $>$. Creación de una colección común. El Frofesional de la Informacion 19:5, 477-485. [CrossRef] 